AperTO - Archivio Istituzionale Open Access dell'Università di Torino

\title{
Analysis of fungal diversity in Orchis tridentata Scopoli
}

\section{This is the author's manuscript}

Original Citation:

Availability:

This version is available http://hdl.handle.net/2318/1503149

since 2016-09-29T15:13:11Z

Published version:

DOI:10.2478/s11535-012-0071-y

Terms of use:

Open Access

Anyone can freely access the full text of works made available as "Open Access". Works made available under a Creative Commons license can be used according to the terms and conditions of said license. Use of all other works requires consent of the right holder (author or publisher) if not exempted from copyright protection by the applicable law. 
This is the author's final version of the contribution published as:

Lorenzo Pecoraro;Mariangela Girlanda;Tiiu Kull;Claudia Perini;Silvia Perotto. Analysis of fungal diversity in Orchis tridentata Scopoli. CENTRAL EUROPEAN JOURNAL OF BIOLOGY. 7 pp: 850-857.

DOI: $10.2478 / \mathrm{s} 11535-012-0071-\mathrm{y}$

The publisher's version is available at:

http://www.springerlink.com/index/pdf/10.2478/s11535-012-0071-y

When citing, please refer to the published version.

Link to this full text:

http://hdl.handle.net/2318/1503149 


\title{
Analysis of fungal diversity in Orchis tridentata Scopoli
}

\author{
Lorenzo Pecoraro ${ }^{1} /$ Mariangela Girlanda $^{2} /$ Tiiu Kull $^{1} /$ Claudia Perini $^{3}$ / Silvia Perotto ${ }^{2}$ \\ ${ }^{1}$ Institute of Agricultural and Environmental Sciences, Estonian University of Life Sciences, 51014, \\ Tartu, Estonia \\ ${ }^{2}$ Department of Plant Biology, University of Torino, 10125, Torino, Italy \\ ${ }^{3}$ Department of Environmental Sciences “G. Sarfatti”, University of Siena, 53100, Siena, Italy
}

\section{Abstract}

We have assessed the identities of fungi associated with Orchis tridentata, an endangered orchid species growing in open woodland and poor grassland of Central and Southern Europe. Fungal diversity in ten $\mathrm{O}$. tridentata adult individuals collected in two protected areas of Central Italy was analysed by means of morphological and molecular methods. Sequencing of the cloned ITS fungal inserts corresponding to the dominant PCR products obtained from amplification of total root DNA with ITS1F and ITS4 primers revealed a variety of fungal species occurring in O. tridentata roots. Among them, members of the basidiomycete families Ceratobasidiaceae, Tulasnellaceae and Hymenogastraceae were recovered, together with ascomycetes belonging to Leptodontidium and Terfezia. The implications of these results in the understanding of O. tridentata biology and for the conservation of this threatened orchid species are discussed.

Keywords: Ascomycetes; Basidiomycetes; Endangered species; Fungal associates; Photosynthetic orchids

\section{Introduction}

The family Orchidaceae, with about 24000 species, is the largest in the plant kingdom [ 1 ] and the vast majority of orchid taxa is well known for its rarity and is threatened in several country throughout the world [ 2, 3 ]. Mycorrhizae have a pivotal impact on orchid growth and metabolism in several plant life stages as well as they influence the distribution and rarity of these delicate plants, more than other important environmental factors such as edaphic conditions or pollinators limitation [ 4 ]. Indeed, orchid mycorrhizal symbiosis are known to affect pollinators visitation as they modify number and size of flowers or nectar production [ 5 ]. Mycorrhizae also influence orchid tolerance to different soil conditions by conferring resistance to toxic metals [ 6 ].

All orchids need to establish a relationship with mycorrhizal fungi for seed germination and subsequent growth and development [ 7,8 ]. After initial development, leading to the protocorm, a non-photosynthetic stage that depends on fungi for carbohydrates, the destiny of the relationship between orchids and fungal symbionts diverges in different species. Achlorophyllous orchids are nutritionally dependent on their fungal partners throughout their life, a strategy named mycoheterotrophy [ 9 ], mixotrophic orchids are photosynthetic at the adult stage, but augment their carbon requirements via mycorrhizal fungi [ 10 ], photosyntethic orchids, that include the majority of species, become fully autotrophic at maturity, but they still 
depend on their fungal associates for carbon nutrition in particular living conditions, as is usual in such cases under low light availability [ 11 ].

Although mycorrhizae are considered essential for orchid biology, little is known about the diversity of mycorrhizal fungi associated with orchids in nature, especially as far as photosynthetic terrestrial species are concerned [ 12, 13 ]. Molecular PCR-based methods have been applied over the last few years to directly identify symbionts in orchid mycorrhizas and have improved our knowledge of the intriguing relationships between fungi and orchids [ 14 ]. Culture-dependent and morphological methods previously used for characterization of orchid mycorrhizas were often not effective in discriminating the fungal symbionts. Indeed, the most of the orchid symbionts are Rhizoctonia -like fungi [ 15, 16 ] belonging to a variety of teleomorphic taxa (Ceratobasidium, Sebacina and Tulasnella), but sexual stages are rarely observed in nature and isolates have very rarely been induced to fruit in culture. As a consequence, morphological discrimination of teleomorphic species for the orchid- associated Rhizoctonia is very difficult [ 17 ]. Molecular techniques were recently used for the identification of mychorrhizal fungi in some orchids species belonging to the genus Orchis [ 5, 18-22]. The identification of symbionts would be very important for the in situ and ex situ conservation of this orchid taxon that shows declining geographic ranges and population extinctions in several species [ 3 ]. In this work, we assessed the diversity of fungi associated with Orchis tridentata Scop. by means of morphological and molecular methods. Knowledge of the identities and roles of mycorrhizal fungi associated with Orchis species, such as $O$. tridentata, is of primary importance for understanding the biology of this threatened orchid genus and contributing to the conservation of these delicate plants. The primary objective of this research was to verify whether the fully photosynthetic orchid $\mathrm{O}$. tridentata, growing in open habitats under high light conditions, was associated with mycorrhizal fungi in adulthood and, in case the study species was colonized by mycobionts, to identify its fungal associates.

\section{Experimental Procedures}

\subsection{Study species and sampling}

Orchis tridentata is a photosynthetic terrestrial orchid with green bluish leaves, the basal ones (3-8) lanceolate, the cauline leaves (1-3) narrower, acute, bract-like. The plant is $15-40 \mathrm{~cm}$ tall with a short, compact, ovoid inflorescence constituted by small, acuminate flowers. Sepals and petals are entirely lilac or pinkish purple veined; labellum is trilobed, white to pale violet, marked with purple spots [ 23 ]. O. tridentata grows in full sun to semi-shade poor grassland, mountain pastures, open woodlands and garrigue on calcareous soil up to $1600 \mathrm{~m}$. This orchid species is widespread in Central and Southern Europe, from Pyrenees to the Caucasus and is quite rare in the west of its area [ 24 ]; it is present in all the Italian regions where the genus Orchis or the whole family Orchidaceae are generally protected [ 25 ]. O. tridentata was collected during the early summer of 2007 and 2008, in two protected areas of Tuscany (Central Italy). We sampled a total of ten flowering adult individuals, five in the "Monte Cetona" and five in the "Monte Penna" (specifically on Monte Rotondo) Natural Reserves, in mountain poor grasslands, on calcareous soil. Root portions were rinsed in water and scrubbed with a brush to remove the most of soil debris. They were subsequently cleaned by sonication with three cycles of 30 $s$ each in an ultrasonic bath, in order to remove remaining soil particles and microorganisms from root surface. Some samples were immediately processed for microscopic analysis and fungal isolation. Root fragments to be used for molecular identification were frozen and stored at $-80^{\circ} \mathrm{C}$.

\subsection{Morphological observations}

Fresh root samples were cut in $1 \mathrm{~cm}$ long portions and cross sectioned to identify regions colonised by pelotons. One section per root portion was checked for the presence of fungal pelotons, that are the primary evidence of the establishment of the orchid mycorrhiza [ 6 ], 
under a light microscope. Root portions with high mycorrhizal colonisation were processed immediately for fungal isolation.

\subsection{Fungal isolation}

Two or three roots per plant were surface-sterilized with consecutive washes of 1:5 sodium hypochlorite $(30 \mathrm{~s})$ and three rinses of sterile water. Eight 3-5 $\mathrm{mm}$ pieces from each root were cultured in malt extract agar (MEA) and potato dextrose agar (PDA) amended with gentamycin $(40 \mathrm{mg} / \mathrm{l})$ and/or chloramphenicol $(50 \mu \mathrm{g} / \mathrm{ml})$. Petri dishes were incubated at room temperature in the dark for up to two months to allow the development of slow-growing mycelia.

\subsection{DNA extraction and ITS amplification}

Total DNA from root samples was extracted following the cetyltrimethyl ammonium bromide (CTAB) procedure modified from Doyle and Doyle [ 26 ]. The polymerase chain reaction (PCR) was performed using the primers ITS1F and ITS4 [ 27 ] in $50 \mu$ reaction volume, containing 38 $\mu$ sterile distilled water, $5 \mu \mathrm{l} 10 \times$ buffer $\left(100 \mathrm{mM}\right.$ Tris- $\mathrm{HCl} \mathrm{pH} 8.3,500 \mathrm{mM} \mathrm{KCl}, 11 \mathrm{mM} \mathrm{Mg} \mathrm{Cl}{ }_{2}$ , $0.1 \%$ gelatine), $1 \mu \mathrm{l} 10 \mathrm{mM}$ dNTP, $1 \mu \mathrm{l}$ of each primer (ITS1 and ITS4), $1.5 \mathrm{U}$ of RED Ta q TM DNA polymerase (Sigma) and $2.5 \mu \mathrm{l}$ of extracted genomic DNA at the appropriate dilution. PCR amplifications were run in a PerkinElmer/Cetus DNA thermal cycler, with 1 cycle of $95^{\circ} \mathrm{C}$ for $5 \mathrm{~min}, 30$ cycles of $94^{\circ} \mathrm{C}$ for $40 \mathrm{~s}, 55^{\circ} \mathrm{C}$ for $45 \mathrm{~s}, 72^{\circ} \mathrm{C}$ for $40 \mathrm{~s}, 1$ cycle of $72^{\circ} \mathrm{C}$ for 7 min. PCR products were electrophoresed in $1 \%$ agarose gel with ethidium bromide and purified with the QIAEX II Gel Extraction Kit (QIAGEN) according to the manufacturer's advice.

\subsection{Cloning}

The purified ITS fragments were cloned into pGEM-T (Promega) vectors that were used to transform XL-2 Blue ultracompetent cells (Stratagene). After transformation, white colonies were randomly taken and transferred to a fresh LB (Luria Broth) plate and the bacterial cells lysed at $95^{\circ} \mathrm{C}$ for $10 \mathrm{~min}$. Plasmid inserts were amplified using the ITS1F and ITS4 primers under the following conditions: $94^{\circ} \mathrm{C}$ for $5 \mathrm{~min}(1 \mathrm{cycle}) ; 94^{\circ} \mathrm{C}$ for $30 \mathrm{~s}, 55^{\circ} \mathrm{C}$ for $45 \mathrm{~s}, 72^{\circ} \mathrm{C}$ for 1 min ( 25 cycles); $72^{\circ} \mathrm{C}$ for 7 min ( 1 cycle).

\subsection{Sequencing of ITS region and sequence analysis}

Cloned ITS inserts, representative of the PCR products initially present were purified with Plasmid Purification Kit (QIAGEN) and sequenced with the same primer pair used for amplification. Dye sequencing was performed on a ABI 310 Genetic Analyzer (Applied Biosystems). Searches for similar sequences allowing taxonomic identification were conducted using the BLASTN algorithm available through the National Center for Biotechnology Information (NCBI, http://www.ncbi.nlm. nih.gov/BLAST/index.html).

\section{Results}

Morphological observations clearly showed fungal colonization in all Orchis tridentata root samples, from both study sites. Microscopy showed densely colonized root cortical cells cluttered with conspicuous fungal pelotons (Figure 1). These abundant intracellular coils were predominantly confined to the cortex, whereas the central stele appeared free from mycelium (Figure $1 \mathrm{a}, \mathrm{b})$. Fungal hyphae had a dominant morphology and details of mycelial structures are visible in root sections (Figure $1 \mathrm{~d}, \mathrm{e}, \mathrm{f}$ ). Hyphae occupied all the cortical cells and were brown, septate, unclamped and thick-walled (8-10 $\mu \mathrm{m}$ diameter). Even though most attempts of in vitro isolation were unsuccessful, one fungal endophyte, putatively symbiont, was isolated from the roots of the $\mathrm{O}$. tridentata sample MC1. Mycelium growing in pure culture could be assigned to the form genus Rhizoctonia on the ground of morphological features. Many nonmycorrhizal endophytes, such as Fusarium species, were isolated together with this 
Rhizoctonia -like taxon. The identification of $\mathrm{O}$. tridentata associated fungi by molecular techniques was successful for all the collected samples, that could be amplified by PCR. Sequences obtained from $O$. tridentata root tissue with the fungal specific primer pair ITS1F/ITS4 revealed that a dominant fungal symbiont belonging to the Ceratobasidiaceae could be associated with this orchid species, irrespective of the site of origin (Table 1 ). Of the 10 analysed $\mathrm{O}$. tridentata individuals, 6 were associated with fungi showing close similarity to symbionts ascribed to the family Ceratobasidiaceae : The closest match for the sequences amplified from sample MC1 (98\% over 885 bp) and MC2 (97\% over 854 bp) was with Ceratobasidiaceae found in roots of Cephalanthera longifolia (L.) Fritsch (DQ182418); the sequences obtained from samples MR1, MR2 and MR3 corresponded to a fungus with a similarity of $91 \%$ (over $880-891 \mathrm{bp}$ ) to Ceratobasidium sp. from Fragaria ananassa Duch in Israel (DQ102402); sequence from sample MR3 (clone e) shared $91 \%$ similarity with sequences from C. cornigerum (Bourdot) D.P. Rogers; the main root fungal endophytes of sample MR5 were fungi with identity to Ceratobasidium sp. (clone a) and Ceratobasidiaceae from Epipactis gigantea Douglas ex Hooker (clone b). Fungal associates with orchid sample MR4 shared 96-97\% similarity with Hymenogastraceae from C. damasonium (Mill.) Druce (clone a) and E. microphylla (Ehrh.) Swartz (clone c). As regards sequences found in sample MC4, an identity of $96 \%$ was recorded with Epulorhiza sp. (anamorphic Tulasnella ) found within Cypripedium macranthos Sw. var. rubense (Kudô) Miyabe et Kudô roots and 98\% identity with an uncultured fungus found in Ophrys sphegodes Mill. in Hungary (clone b); clone c from the same sample, shared $97 \%$ of similarity with Epulorhiza sp. (EU218890). Sequences from sample MC3 matched to Leptodontidium sp. (DQ148411) isolated from the roots of an alpine plant Saussurea involucrata Kar. et Kir. ex Maxim and to an unidentified fungus from Pterostylis nutans $\mathrm{R}$. Br. whereas the closest match for sample MC5 was with mycorrhizal hypogeous ascomycetes Terfezia sp. (DQ061109).
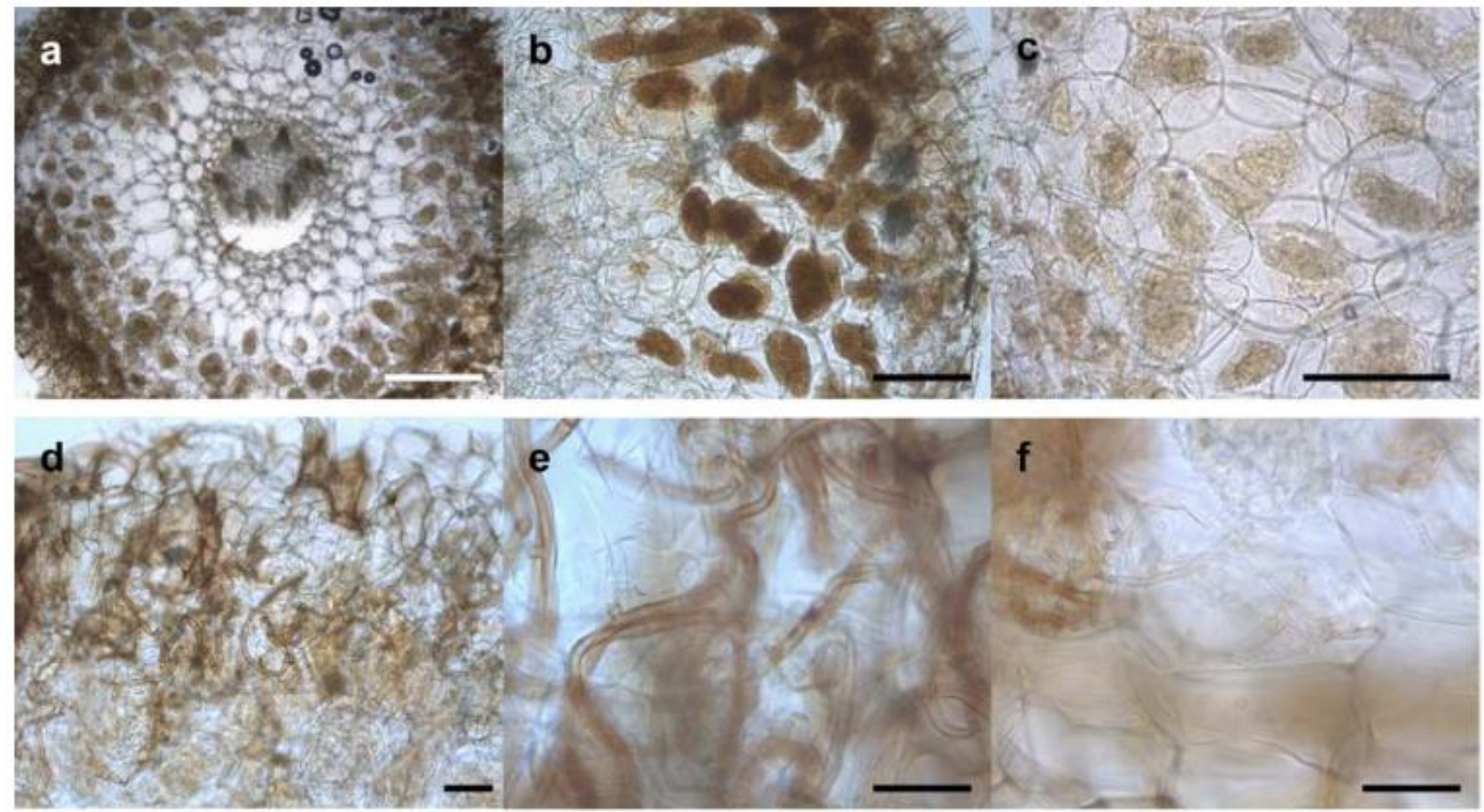

Figure 1. O. tridentata mycorrhizal roots: (a-c) Cross sections showing fungal pelotons in orchid root cells. (d-f) Details of fungal hyphae forming coils. Scale bars: $500 \mu \mathrm{m}(a), 200 \mu \mathrm{m}(b, c), 100 \mu \mathrm{m}(d, e, f)$. 


\begin{tabular}{|c|c|c|c|c|c|c|}
\hline Sample & Clone & GenBank & $\begin{array}{l}\text { Best BLAST match(es) } \\
\text { accession code }\end{array}$ & $\begin{array}{l}\text { Accession } \\
\text { code }\end{array}$ & $\begin{array}{l}\text { Overlap } \\
\text { length }\end{array}$ & $\%$ match \\
\hline \multirow[t]{2}{*}{ MC1 } & isolated & JN683860 & Ceratobasidiaceae (from Cephalanthera longifolia) & DQ182418 & 885 & $98 \%$ \\
\hline & & & Rhizoctonia sp. (from Teucrium dunense) & DQ865086 & 795 & $96 \%$ \\
\hline \multirow[t]{3}{*}{ MC2 } & a & JN683842 & Fusarium sp. & DQ446211 & 989 & $99 \%$ \\
\hline & e & JN683843 & Basidiomyoete (from mixed hardwood soil) & AY970109 & 872 & $93 \%$ \\
\hline & & & Ceratobasidiaceae (from Cephalanthera longifolia) & DQ182418 & 854 & $97 \%$ \\
\hline \multirow[t]{4}{*}{ MC3 } & $\circ$ & JN683844 & Fungus (from Pterostylis nutans) & EF090490 & 660 & $94 \%$ \\
\hline & & & Leptodontidium sp. (from Saussurea involucrata) & DQ148411 & 658 & $94 \%$ \\
\hline & $d$ & JN683845 & Fusarium oxysporum & DQ535184 & 992 & $99 \%$ \\
\hline & e & JN683846 & Fusarium sp. & AJ 279478 & 1014 & $100 \%$ \\
\hline \multirow[t]{3}{*}{$\mathrm{MC4}$} & b & JN683847 & Epulorhiza sp. (from Cypripedium macranthos var. rubense) & AB369932 & 1077 & $96 \%$ \\
\hline & & & Fungus (host=Ophrys sphegodes) & AM697902 & 1048 & $99 \%$ \\
\hline & $\circ$ & JN683848 & Enulorhiza sp. & EU218890 & 267 & $97 \%$ \\
\hline \multirow[t]{2}{*}{ MC5 } & a & JN683849 & Candida sp. & DQ911447 & 174 & $84 \%$ \\
\hline & $d$ & JN683850 & Terfezia sp. & DQ061109 & 324 & $83 \%$ \\
\hline \multirow[t]{2}{*}{ MR1 } & a & JN683851 & Basidiomycete (from sandy loam soil) & FM866373 & 856 & $93 \%$ \\
\hline & $b$ & JN683852 & Ceratobasidium sp. (from Fragaria sp.) & DQ102402 & 880 & $91 \%$ \\
\hline \multirow[t]{2}{*}{ MR2 } & a & JN683853 & Basidiomycete (from sandy loam soil) & FM866373 & 959 & $95 \%$ \\
\hline & & & Ceratobasidium sp. (from Fragaria sp.) & DQ102402 & 883 & $91 \%$ \\
\hline \multirow[t]{3}{*}{ MR3 } & a & JN683854 & Basidiomyoete (from sandy loam soil) & FM866373 & 959 & $95 \%$ \\
\hline & & & Ceratobasidium sp. (from Fragaria sp.) & DQ102402 & 891 & $91 \%$ \\
\hline & e & JN683855 & Ceratobasidium cornigerum & EU273525 & 872 & $91 \%$ \\
\hline \multirow[t]{3}{*}{ MR4 } & a & JN683856 & Hymenogastraceae (from Cephalanthera damasonium) & AY 634136 & 1195 & $97 \%$ \\
\hline & & & Hymenogaster citrinus & EU784360 & 1110 & $95 \%$ \\
\hline & $\circ$ & JN683857 & Hymenogastraceae (from Epipactis microphylla) & AY351628 & 1055 & $96 \%$ \\
\hline \multirow[t]{2}{*}{ MR5 } & a & JN683858 & Ceratobasidium sp. & EU218894 & 874 & $92 \%$ \\
\hline & b & JN683859 & Ceratobasidiaceae (from Epipactis gigantea) & AY634119 & 769 & $99 \%$ \\
\hline
\end{tabular}

Table 1. Closest matohes from BLAST searches of fungal sequences amplified from O. tridentata roots collected in Monte Cetona (samples MC1. MC5) and Monte Rotondo (samples MR1-MR5). Deposited accession code, accession code for the closest GenBank matches, sequence identity (\% match) and overlap of each matoh are reported.

\section{Discussion}

This study has analyzed, for the first time, the fungal diversity associated with roots of Orchis tridentata, using both morphological culture-dependent and PCR- based methods. A high level of fungal colonization was clearly visible in $\mathrm{O}$. tridentata root by morphological observations. Roots of all orchid samples contained fungal pelotons in their cortical cells, showing the typical features of orchid mycorrhiza, as described by several authors [ $6,7,28,29$ ]. This observation is in agreement with recent works that show the presence of mycorrhizal symbiosis in several green orchids. Cameron et al. demonstrated for the first time mutualism in Goodyera repens (L.) R. Brown mycorrhiza, with carbon passing from the orchid to the fungus, in return for mineral nutrient passing from the fungus to the orchid [ 30 ]. More recently, Liebel et al . and Girlanda et al . demonstrated that some photosynthetic orchid species belonging to the genus Orchis depend on fungi as a source of carbon, using natural abundance analysis of ${ }_{13} \mathrm{C}$ [ 19 , 31 ]. Only one Rhizoctonia -like fungus, characterized by right-angle branching, a constriction at the branch point, and a septum in the branch hypha near its point of origin, could be isolated from O. tridentata analysed roots (sample MC1). The ITS region of this strain showed an identity of $98 \%$ with Ceratobasidiaceae found in Cephalanthera longifolia [ 28 ], similarly to sequences obtained from total DNA extracted from roots of other orchid sample (MC2). In the 
previous work on C. longifolia [28 ] two Ceratobasidium were found, but they were not reported to form pelotons. For this reason, the authors were not sure about the symbiotic status of these fungi as some Ceratobasidiaceae are plant parasites or simply grow endophytically, without being mycorrhizal [ 16, 32, 33 ]. Anyway, the majority of fungi that have been recorded as orchid mycorrhizal symbionts belong to the anamorphic form-genus Rhizoctonia and most of the orchid-associated Rhizoctonia species belong to the Ceratobasidiaceae, Sebacinaceae and Tulasnellaceae [ $7,15,17,34$ ]. Even if morphology is the first choice for species discrimination in eukaryotes, in most fungi where complex fruit bodies are absent, such as the three families of orchid symbionts above mentioned, morphological species delimitation is difficult. Moreover, symbionts of a number of orchids are difficult or impossible to cultivate axenically [ $9,35,36$ ], as confirmed from the results obtained through the in vitro isolation attempts performed in our work. As a consequence, molecular methods, based on PCR, used to directly identify fungi within $O$. tridentata roots, have been essential to characterize fungal diversity in this orchid. A large number of Ceratobasidiaceae were found after cloning of the PCR amplification products, while in vitro isolation failed to reveal the presence of these fungi in the majority of samples. Sequences from samples MR1, MR2 and MR3 shared similarity with Ceratobasidium sequences from Fragaria ananassa plants collected in Israel [ 37 ]. The closest match for the sequences amplified from sample MR5 was with Ceratobasidiaceae found in roots of Epipactis gigantea collected in California and Oregon [ 38 ]. These typical rhizoctonia-forming orchid mycorrhizal fungi dominated the roots of the stream- dwelling $\mathrm{E}$. gigantea. As ceratobasidioid fungi have been found as symbionts or putatively symbionts of several orchid species, such as C. damasonium [ 10 ], C. longifolia [ 28 ], Cypripedium spp. [ 39 ], Dactylorhiza majalis (Reichenbach) P.F. Hunt et Summerhayes, E. gigantea , E. helleborine (L.) Crantz, E. palustris (L.) Crantz and Platanthera chlorantha (Cust.) Rchb. [ 38 ], Ionopsis utricularioides (Sw.) Lindl. [ 40 ], Pterostylis nutans [ 41 ], Tolumnia variegata (Sw.) Braem [ 42 ], the ceratobasidioid fungi reported in this study could have the same trophic relationship with $\mathrm{O}$. tridentata. Roots of sample MR4 were colonised by fungi with similarity to Hymenogastraceae found in C. damasonium [ 38 ] and E. microphylla [ 43 ]. These basidiomycetes, that usually produce hypogeous basidiomata during the sexual phase, belong to a family that mostly contains obligate ecto-mycorrhizal fungi. Sequences amplified from sample MC4 matched to Epulorhiza sp. from juvenile plant of C. macranthos var. rubense [ 44 ]. All the fungi isolated from C. macranthos grew well on nutrition-poor media, suggesting that the nutritional demands of these isolates differ from those of typical saprophytic Rhizoctonia growing well on common nutrition-rich media. After all, Epulorhiza belongs to Tulasnellaceae that are well-known to associate symbiotically with several orchid taxa, including some Orchis species [ $5,18,19,45]$. Actually, some papers have shown that tulasnelloid fungi are dominant in mycorrhizal associations with Orchis spp., for instance in O. militaris L. [6,20-22] that is closely related to $O$. tridentata (probably a monophyletic group, with five species derived from a common ancestor close to $\mathrm{O}$. militaris and isolated by chromosome reorganisation from $\mathrm{O}$. tridentata ) [ 24 ]. The small number of sequences related to Tulasnella amplified from $\mathrm{O}$. tridentata could be influenced by primers used in fungal ITS regions amplification. Indeed, the primer pair ITS1F/ITS4 is very effective for the amplification of ITS region from essentially all Eumycota, but it does not effectively amplify some core species within the Tulasnellaceae [ 17 ]. Sequences of ascomycetes were obtained from samples MC3 and MC5. Ascomycetous fungi from sample MC3 shared 94\% similarity with Leptodontidium sp. found in Saussurea involucrata [ 46 ]. Resynthesis study was conducted to clarify the relationship between the darkseptate root endophyte and $S$. involucrata. Seedlings of the host plant, inoculated with endophytes appeared healthy with no external symptoms of disease and their dry weights increased significantly compared to controls. Fungi belonging to the genus Leptodontidium are common fungal endophytes that have been found in many orchid species worldwide [ 10,28 , 38 , 41, 47 ]. Physiological studies are needed in order to clarify the role of these fungi in orchids. Sequences from sample MC3 also shared 94\% similarity with an uncultured fungus from $P$. nutans sampled in Australia [ 41 ], but there was not evidence for a symbiotic association between the unidentified fungus and the terrestrial orchid. The closest match for 
sequences amplified from sample MC5 was with Terfezia sp. Ascomycetes belonging to this genus, known as "desert truffles", are mycorrhizal fungi forming hypogeous fruit bodies, associated with shrubs such as Helianthemum sp. [ 48 ] in semiarid condition. We cannot fully exclude that they form orchid mycorrhizae. Indeed, although basidiomycetes are the most important group of orchid fungi, several authors have shown through ITS sequencing that ascomycetes can form mycorrhizal association with orchid species [ 10, 43 ]. In this study, we have demonstrated that $O$. ridentata associates with fungi heavily colonizing the roots. Among them, Ceratobasidiaceae could be dominant, as suggested by PCR amplification and cloning of fungal rDNA, but further studies, based on the use of different primers recently developed to specifically target tulasnelloid fungi [17], are needed to deeply characterize the diversity of fungal symbionts in $O$. tridentata. Other fungi found in the roots of the study species, such as Hymenogastraceae, Epulorhiza sp. and some ascomycetous fungi, could be also mycorrhizal partners. Further ecological and physiological studies will be necessary to flesh out whether these endophytes are truly mycorrhizal. The biology of $O$. tridentata cannot be fully understood without an in-depth analysis of its fungal symbionts. The results of this work could have direct implications for the conservation of this threatened orchid. Indeed, management measures for the conservation and restoration of orchid populations require knowledge of the host specificity, distribution and abundance of fungal symbionts in natural habitats [ 49 ]. For instance, the presence of appropriate fungal species is needed for long-term success of traslocation efforts [ 20 ]. Transplantation into the nature of orchid seedlings associated with their mycorrhizal partners and in situ land inoculation with fungal symbionts could be of primary importance for conservation efforts [ 22,50 ].

\section{Acknowledgements}

We thank the Estonian Science Foundation and the European Social Fund (Mobilitas ostdoctoral Research Grant MJD135) for financial support

\section{References}

- [1] Dressler R.L., How many orchid species?, Selbyana, 2005, 26, 155-158

- [2] I.U.C.N., IUCN Red List Categories, IUCN: Gland, Switzerland, 1994

- [3] Kull T., Hutchings M.J., A comparative analysis of decline in the distribution ranges of orchid species in Estonia and the United Kingdom, Biol. Conserv., 2006, 129, 31-39 http://dx.doi.org/10.1016/j.biocon.2005.09.046

- [4] Kull T., Kull K., How orchids regulate their numbers, In: Nair H., Arditti J. (Eds.), Proceedings of the 17th world Orchid Conference (24 April-1 May 2002, Shah Alam, Malaysia), Shah Alam, 2002, Natural History Publications (Borneo), Kota Kinabalu, Sabah, Malaysia, 2005, 173-177

- [5] Schatz B., Geoffroy A., Dainat B., Bessière J.M., Buatois B., Hossaert-McKey M., Selosse M.A., A case study of modified interactions with symbionts in a hybrid Mediterranean orchid, Am. J. Bot., 2010, 97, 1278-1288 http://dx.doi.org/10.3732/ajb.0900303

- [6] Shefferson R.P., Kull T., Tali K., Mycorrhizal interaction of orchids colonizing Estonian mine tailings hills, Am. J. Bot., 2008, 95, 156-164 http://dx.doi.org/10.3732/ajb.95.2.156

- [7] Rasmussen H.N., Terrestrial orchids: From seed to mycotrophic plant, Cambridge University Press, Cambridge, UK, 1995 http://dx.doi.org/10.1017/CBO9780511525452

- [8] Kull T., Arditti J., Orchid Biology: Reviews and Perspectives, VIII, Kluwer Academic Publishers, Dordrecht, 2002

- [9] Leake J.R., The biology of mycoheterotrophic ('saprophytic') plants, Tansley Review No. 69, New Phytol., 1994, 127, 171-216 http://dx.doi.org/10.1111/j.1469-8137.1994.tb04272.x 
- [10] Julou T., Burghardt B., Gebauer G., Berveiller D., Damesin C., Selosse M.A., Mixotrophy in Orchids: insights from a comparative study of green individuals and nonphotosynthetic individuals of Cephalantera damasonium, New Phytol., 2005, 166, 639$653 \mathrm{http}: / / \mathrm{dx}$.doi.org/10.1111/j.1469-8137.2005.01364.x

- [11] Gebauer G., Meyer M., 15N and 13C natural abundance of autotrophic and mycoheterotrophic orchids provides insight into nitrogen and carbon gain from fungal association, New Phytol., 2003, 160, 209-223 http://dx.doi.org/10.1046/j.14698137.2003.00872.x

- [12] Dearnaley J.D.W., Further advances in orchids mycorrhizal research, Mycorrhiza, 2007, 17, 475-486 http://dx.doi.org/10.1007/s00572-007-0138-1

- [13] Bidartondo M.I., Read D.J., Fungal specificity bottlenecks during orchid germination and development, Mol. Ecol., 2008, 17, 3707-3716

- [14] Selosse M.A., Cameron D.D., Introduction to a virtual special issue on mycoheterotrophy: the New Phytologist sheds light on non-green plants, New Phytol., 2010, 185, 591-593 http://dx.doi.org/10.1111/j.1469-8137.2009.03151.x

- [15] Otero J.T., Ackerman J.D., Bayman P., Diversity and host specificity of endophytic Rhizoctonia-like fungi from tropical orchids, Am. J. Bot., 2002, 89, 1852-1858 http://dx.doi.org/10.3732/ajb.89.11.1852

- [16] Roberts P., Rhizoctonia-forming fungi: A taxonomic guide, Kew Royal Botanic Gardens, Surrey, UK, 1999

- [17] Taylor D.L., McCormick M.K., Internal transcribed spacer primers and sequences for improved characterization of basidiomycetous orchid mycorrhizas, New Phytol., 2008, 177, 1020-1033 http://dx.doi.org/10.1111/j.1469-8137.2007.02320.x

- [18] Pecoraro L., Girlanda M., Kull T., Perini C., Perotto S., Molecular identification of root fungal associates in Orchis pauciflora Tenore, Plant Biosystems, DOI: 10.1080/11263504.2011.634447 (in press)

- [19] Girlanda M., Segreto R., Cafasso D., Liebel H.T., Rodda M., Ercole E., et al., Mediterranean meadow photosynthetic orchids feature partial mycoheterotrophy and specific mycorrhizal associations, Am. J. Bot., 2011, 98, 1148-1163 http://dx.doi.org/10.3732/ajb.1000486

- [20] Jacquemyn H., Honnay O., Cammue B.P.A., Brys R., Lievens B., Low specificity and nested subset structure characterize mycorrhizal associations in five closely related species of the genus Orchis, Mol. Ecol., 2010, 19, 4086-4095 http://dx.doi.org/10.1111/j.1365294X.2010.04785.x

- [21] Jacquemyn H., Brys R., Cammue B.P.A., Honnay O., Lievens B., Mycorrhizal associations and reproductive isolation in three closely related Orchis species, Ann. Bot., 2011, 107, 347-356 http://dx.doi.org/10.1093/aob/mcq248

- [22] Vendramin E., Gastaldo A., Tondello A., Baldan B., Villani M., Squartini A., Identification of two fungal endophytes associated with the endangered orchid Orchis militaris L., J. Microbiol. Biotechnol., 2010, 20, 630-636

- [23] Rossi W., Orchids of Italy [Orchidee d'Italia], Quad. Cons. Natura, 15, Min. AmbienteIst. Naz. Fauna Selvatica, 2002

- [24] Delforge P., Orchids of Britain \& Europe, Harper Collins Publishers, Basingstoke, 1995

- [25] Alonzi A., Ercole S., Piccini C., La protezione delle specie della flora e della fauna selvatica: quadro di riferimento legislativo regionale, APAT Rapporti 75/2006, 2006

- [26] Doyle J.J., Doyle J.L., Isolation of plant DNA from fresh tissues, Focus, 1990, 12, 1315

- [27] Gardes M., Bruns T.D., ITS primers with enhanced specificity for basidiomycetes applications to the identification of mycorrhizae and rusts, Mol. Ecol., 1993, 2, 113-118 http://dx.doi.org/10.1111/j.1365-294X.1993.tb00005.x 
- [28] Abadie J.C., Püttsepp Ü., Gebauer G., Faccio A., Bonfante P., Selosse M.A., Cephalanthera longifolia (Neottieae, Orchidaceae) is mixotrophic: a comparative study between green and nonphotosynthetic individuals, Can. J. Bot., 2006, 84, 1462-1477 http://dx.doi.org/10.1139/b06-101

- [29] Smith S.E., Read D.J., Mycorrhizal Symbiosis, 3rd ed., Academic Press, San Diego, California, 2008

- [30] Cameron D.D., Leake J.R., Read D.J., Mutualistic mycorrhiza in orchids: evidence from plantfungus carbon and nitrogen transfers in the green-leaved terrestrial orchid Goodyera repens, New Phytol., 2006, 171, 405-416 http://dx.doi.org/10.1111/j.14698137.2006.01767.x

- [31] Liebel H.T., Bidartondo M.I., Preiss K., Segreto R., Stöckel M., Rodda M., et al., C and $\mathrm{N}$ stable isotope signatures reveal constraints to nutritional modes in orchids from the Mediterranean and Macaronesia, Am. J. Bot., 2010, 97, 903-912 http://dx.doi.org/10.3732/ajb.0900354

- [32] Sen R., Hietala A.M., Zelmer C.D., Common anastomosis and internal transcribed spacer RFLP groupings in binucleate Rhizoctonia isolates representing root endophytes of Pinus silvestris, Ceratorhiza spp. from orchid mycorrhizas and a phytopathogenetic anastomosis group, New Phytol., 1999, 144, 331-341 http://dx.doi.org/10.1046/j.1469-8137.1999.00522.x

- [33] Grönberg H., Kaparakis G., Sen R., Binucleate Rhizoctonia (Ceratorhiza spp.) as nonmycorrhizal endophytes alter Pinus sylvestris L. seedling root architecture and effect growth of rooted cuttings, Scand. J. For. Res., 2006, 21, 450-457 http://dx.doi.org/10.1080/02827580601019662

- [34] Hadley G., Orchid mycorrhizal, In: Arditti J. (Ed.), Orchid biology: reviews and perspectives, II, Cornell University Press, Ithaca, NY, 1982

- [35] McCormick M.K., Whigham D.F., O’Neill J., Mycorrhizal diversity in photosynthetic terrestrial orchids, New Phytol., 2004, 163, 425-438 http://dx.doi.org/10.1111/j.14698137.2004.01114.x

- [36] Girlanda M., Selosse M.A., Cafasso D., Brilli F., Delfine S., Fabbian R., et al., Inefficient photosynthesis in the Mediterranean orchid Limodorum abortivum is mirrored by specific association to ectomycorrhizal Russulaceae, Mol. Ecol., 2006, 15, 491-504 http://dx.doi.org/10.1111/j.1365-294X.2005.02770.x

- [37] Sharon M., Freeman S., Kuninaga S., Sneh B., Genetic diversity, anamostosis groups and virulence of Rhizoctonia spp. from strawberry, Eur. J. Plant. Pathol., 2007, 117, 247-265 http://dx.doi.org/10.1007/s10658-006-9091-7

- [38] Bidartondo M.I., Burghardt B., Gebauer G., Bruns T.D., Read D.J., Changing partners in the dark: isotopic and molecular evidence of ectomycorrhizal liaisons between forest orchids and trees, Proceedings of the Royal Society of London B, 2004, 271, 1799-1806 http://dx.doi.org/10.1098/rspb.2004.2807

- [39] Shefferson R.P., Weiss M., Kull T., Taylor D.L., High specificity generally characterizes mycorrhizal association in rare lady's slipper orchids, genus Cypripedium, Mol. Ecol., 2005, 14, 613-626 http://dx.doi.org/10.1111/j.1365-294X.2005.02424.x

- [40] Otero J.T., Flanagan N.S., Herre E.A., Ackerman J.D., Bayman P., Widespread mycorrhizal specificity correlates to mycorrhizal function in the neotropical, epiphytic orchid Ionopsis utricularioides (Orchidaceae), Am. J. Bot., 2007, 94, 1944-1950 http://dx.doi.org/10.3732/ajb.94.12.1944

- [41] Irwin M.J., Bougoure J.J., Dearnaley J.D.W., Pterostylis nutans (Orchidaceae) has a specific association with two Ceratobasidium root associated fungi across its range in Eastern Australia, Mycoscience, 2007, 48, 231-239 http://dx.doi.org/10.1007/s10267-007-0360-x

- [42] Otero J.T., Bayman P., Ackerman J.D., Variation in mycorrhizal performance in the epiphytic orchid Tolumnia variegata in vitro: the potential for natural selection, Evol. Ecol., 2005, 19, 29-43 http://dx.doi.org/10.1007/s10682-004-5441-0 
- [43] Selosse M.A., Faccio A., Scappaticci P., Bonfante P., Chlorophyllous and achlorophyllous specimens of Epipactis microphylla (Neottieae, Orchidaceae) are associated with ectomycorrhizal septomycetes, including truffles, Microbiol. Ecol., 2004, 47, 416-426 http://dx.doi.org/10.1007/s00248-003-2034-3

- [44] Shimura H., Sadamoto M., Matsuura M., Kawahara T., Naito S., Koda Y., Characterization of mycorrhizal fungi isolated from the threatened Cypripedium macranthos in a northern island of Japan: two phylogenetically distinct fungi associated with the orchid, Mycorrhiza, 2009, 19, 525-534 http://dx.doi.org/10.1007/s00572-009-0251-4

- [45] Lievens B., van Kerckhove S., Juste A., Cammue B.P.A., Honnay O., Jacquemyn H., From extensive clone libraries to comprehensive DNA arrays for the efficient and simultaneous detection and identification of orchid mycorrhizal fungi, J. Microbiol. Methods, 2010, 80, 76-85 http://dx.doi.org/10.1016/j.mimet.2009.11.004

- [46] Wu L., Guo S., Interaction between an isolate of dark-septate fungi and its host plant Saussurea involucrata, Mycorrhiza, 2008, 18, 79-85 http://dx.doi.org/10.1007/s00572-0070159-9

- [47] Currah R.S., Smreciu A., Hambleton S., Mycorrhizae and mycorrhizal fungi of boreal species of Platanthera and Coeloglossum (Orchidaceae), Can. J. Bot., 1990, 68, 1171-1181 http://dx.doi.org/10.1139/b90-149

- [48] Morte A., Lovisolo C., Schubert A., Effect of drought stress on growth and water relations of the mycorrhizal association Helianthemum almeriense-Terfezia claveryi, Mycorrhiza, 2000, 10, 115-119 http://dx.doi.org/10.1007/s005720000066

- [49] Batty A.L., Dixon K.W., Brundrett M., Sivasithamparam K., Constraints to symbiotic germination of terrestrial orchid seed in a mediterranean bushland, New Phytol., 2001, 152, 511-520 http://dx.doi.org/10.1046/j.0028-646X.2001.00277.x

- [50] Liu H., Luo Y., Liu H., Studies of Mycorrhizal Fungi of Chinese Orchids and Their Role in Orchid Conservation in China-A Review, Bot. Rev., 2010, 76, 241-262 http://dx.doi.org/10.1007/s12229-010-9045-9 